December 2011

\title{
Leaving the Parental Home: An Overview of the Current State of Genocide Studies
}

Daniel Feierstein

Follow this and additional works at: https://digitalcommons.usf.edu/gsp

\section{Recommended Citation}

Feierstein, Daniel (2011) "Leaving the Parental Home: An Overview of the Current State of Genocide Studies," Genocide Studies and Prevention: An International Journal: Vol. 6: Iss. 3: Article 7.

Available at: https://digitalcommons.usf.edu/gsp/vol6/iss3/7

This Articles is brought to you for free and open access by the Open Access Journals at Digital Commons @ University of South Florida. It has been accepted for inclusion in Genocide Studies and Prevention: An International Journal by an authorized editor of Digital Commons @ University of South Florida. For more information, please contact digitalcommons@usf.edu. 


\title{
Leaving the Parental Home: An Overview of the Current State of Genocide Studies ${ }^{1}$
}

\author{
Daniel Feierstein \\ Centre for Genocide Studies at the National University of \\ Tres de Febrero
}

This article examines current developments in genocide studies, focusing specifically on three main areas of conflict and debate between different perspectives: the question of how to define genocide, causal models and comparative studies, and prevention. Further, this article presents an analysis of Eurocentrism in the field, arguing that genocide studies needs a broader scope to include new and unique perspectives from all areas of the world. What is needed, in fact, is genuine intercultural dialogue, which can transform the field of genocide studies into a broad, culturally diverse field.

Key words: genocide studies, genocide prevention, social sciences

Genocide studies, in its broad sense, emerged in the late 1970s and early 1980s from a fertile intersection of law, history, psychology, and social science. Most early work was published in English in the United States, Great Britain, Canada, and Israel. Since the early 1990s, however, genocide studies has grown in two parallel directions. First, it has become more interdisciplinary, bringing fresh insights from political science, anthropology, philosophy, aesthetics, and psychoanalysis. Second, it has become more intercultural. Works are now being published in many languages, including Slavic languages (Russian, Serbo-Croatian, and Bosnian), Spanish and Portuguese (from the Americas as well as the Iberian Peninsula), French, Italian, and Hungarian. In short, a new generation of scholars is beginning to contribute to the field while also engaging in debates over critical issues with the founding fathers.

In this article I examine three main areas of conflict and debate between different perspectives: (1) the question of how to define genocide, (2) causal models and comparative studies, and (3) the link to prevention.

In doing so, I hope to clear the ground for genuine intercultural dialogue. In my view, such dialogue is vital to transforming genocide studies from a minor subdiscipline into a broad, interdisciplinary, and culturally diverse field for exploring and modifying social practices.

\section{The Question of Definitions}

Genocide studies first emerged largely as a result of legal and sociological debates about the adequacy of the Convention on the Prevention and Punishment of the Crime of Genocide adopted by the United Nations General Assembly in 1948 (UNCG). Most early work highlighted the serious shortcomings in the legal definition of genocide (especially the exclusion of certain groups) and proposed new definitions. Examples of this approach can be found in the work of Vahakn Dadrian, Irving Louis Horowitz, Frank Chalk and Kurt Jonassohn, Helen Fein, Israel Charny, Barbara Harff and Ted Gurr, and Ben Kiernan, among others. ${ }^{2}$ One of the few exceptions

Daniel Feierstein, "Leaving the Parental Home: An Overview of the Current State of Genocide Studies." Genocide Studies and Prevention 6, 3 (December 2011): 257-269. (C) 2011 Genocide Studies and Prevention. doi:10.3138/gsp.6.3.257 
was the pioneering work of Leo Kuper, who finally accepted the legal definition with the following reservations:

This is not to say that I agree with the definition. On the contrary, I believe a major omission to be in the exclusion of political groups from the list of groups protected. In the contemporary world, political differences are at the very least as significant a basis for massacre and annihilation as racial, national, ethnic or religious differences. Then too, the genocides against racial, national, ethnic or religious groups are generally a consequence of, or intimately related to, political conflict. ${ }^{3}$

Disagreements over definitions led scholars to develop a rich variety of concepts based on alternative definitions of genocide. However, there is no consensus about which of these definitions should or could replace the one accepted by the 1948 UNCG.

The disagreements have been reflected in the wide disparity between scholars in regards to which cases of mass killing merit the label of genocide. A classic example of paradigmatic and contradictory views is the opposing views of Steven L. Katz and Israel W. Charny. Katz argued that the Holocaust is the only genocide that has occurred in modern history, while Charny proposed a "generic definition" of genocide, which allows a much greater number of cases of mass killing to be identified as "genocides" and may include even the destruction of the environment (ecocide) or other types of human losses. This discussion typifies the wide conceptual gap between exclusivism and inclusivism and has aptly been dubbed the "Katz-Charny conundrum" by Henry Huttenbach. ${ }^{4}$

During the negotiations that led up to the Rome Statute for an International Criminal Court (ICC) in 1998, all attempts to introduce a broader definition of genocide failed and the formal definition of the 1948 UNCG was adopted. ${ }^{5}$ At the same time, though, the Rome Statute introduced a new, extended definition of "crimes against humanity." This persuaded many scholars to change their approach and accept the inadequate definition of the 1948 UNCG as the only possible way of establishing common ground within the academic community.

In this regard, Matthias Bjornlund, Eric Markusen and Martin Mennecke argue,

[I]t is widely recognized that the prevention of genocide depends mainly on political will, and the definition of genocide that politicians rely on is an authoritative interpretation of the UNGC [United Nations Convention on the Prevention and Punishment of the Crime of Genocide]. Less authoritative and widespread definitions cannot be expected to impact significantly on decision makers. ${ }^{6}$

Further, they claim,

It is impossible to find a workable definitional core that completely satisfies every scholar, but hopefully exclusivists as well as inclusivists are able to see the advantages of sharing some widely recognized common ground. Perhaps, genocide scholars who have given up on the UNGC might be well-advised to reconsider it, at least as a workable alternative to the present anarchy in definitions. ${ }^{7}$

Indeed, William Schabas, a legal scholar, has suggested that the debate over definitions should be closed. In his view, "instead of enlarging the definition of genocide in order to accomplish this [i.e., fill the gaps in the law], the international community should opt for an expanded view of crimes against humanity instead." 8

Previous to this, Schabas had advocated for relegating "the concept of genocide to the more general and more easily applicable concept of crimes against humanity." 9 While this position has been accepted by some pioneers of genocide studies, this mainly 
juridical "consensus" has been, and should be, strongly questioned for two primary reasons:

1. The concept of crimes against humanity often refers to the indiscriminate killing of civilians and so lacks the explanatory power of the concept of genocide, which refers to the attempted destruction of a group.

2. The wording of Article II of the 1948 Genocide Convention violates the principle of equality before the law by placing some target groups under its protection and not others. The law defines the crimes as actions, not allowing us to distinguish between those who suffer from these actions. Homicide is the killing of a person, any person. If genocide is the intention to annihilate a group as such, it does not matter which groups are targeted, and it is contrary to the principle of equality before the law to decide otherwise. Any group that might be targeted should also be protected. International law allows the principle of equality before the law to take precedence over other particular laws. To violate this principle is to violate the concept of law itself. $^{10}$

There have been alternative proposals proffered within sociology and anthropology. Harff and Gurr (1988), for example, developed the concept of politicide to refer to the destruction of political groups. ${ }^{11}$ However, the distinction between politicide and genocide is difficult to apply in practice, and Harff and Gurr themselves concluded that most of the cases they had examined were geno-politicides. In addition, the term politicide has not been widely accepted by legal experts and courts and does not resolve the legal problem of Article II of the 1948 UNCG, that is, its violation of legal principles and its use of different legal definitions for the same practice directed at different victims.

The geopolitical dimensions of the debate over definitions should not be underestimated. As Schabas suggested, in the current century international criminal courts have treated nearly all human rights violations as crimes against humanity and few as genocide (that is, the sentences of the International Criminal Tribunal for the former Yugoslavia (ICTY) and International Criminal Tribunal for Rwanda (ICTR) and cases filed by the ICC). The treatment of most human rights violations as crimes against humanity blurs the distinction between, say, sporadic instances of violent repression and campaigns of annihilation.

This leveling of differences has then been used to justify the need for "intervention" (particularly, military intervention) in all kinds of cases, as the current situation in Libya has illustrated. Thus, outrage at the Nazi Holocaust or the Rwandan massacres can be capitalized on to justify military interventions all over the world, from Iraq, Afghanistan, and Libya to possible like cases in Korea, Iran, or some Latin American democracies that threaten US interests, such as Venezuela, Bolivia, and Ecuador.

Of course, scholars who argue for this type of conceptual leveling would not necessarily support military intervention in any of these countries. But this is how their work has been used by politicians who are willing to override established legal principles and definitions. We will return to this issue later under the discussion of prevention.

Suffice it to say for now that there are currently two positions on the problem of definitions. On the one hand, a significant number of researchers now follow the definition of the UNCG, including many of the Anglo-Saxon pioneers who had formerly rejected it before the Rome Statute of 1998. Of course, not all these scholars 
think alike, and there are many exceptions and nuances, such as Israel Charny and Barbara Harff, among others.

On the other hand, most scholars outside the Anglo-Saxon world-for example, in Argentina, Bosnia-Herzegovina, Cambodia, Colombia, or Uruguay—are still struggling, even in courts, to find an acceptable definition for genocide. ${ }^{12}$ They avoid using the definition of the UNCG for historical and sociological purposes because it violates the principle of equality before the law. At the same time, they are concerned that, for want of a satisfactory definition, international condemnation of any human rights violation, severe or otherwise, could be used to justify the violation of a state's territorial sovereignty.

It should be noted that many states have, in recent years, adopted much better legal definitions of genocide than that of the UNCG. This has provided fresh impetus to continue the struggle for a more precise international definition in keeping with the principle of equality before the law. ${ }^{13}$

\section{Causal Models and Comparative Studies}

The debate over causation has been one of the richest and most productive in the development of genocide studies. Work in this area is characterized by a wide range of explanations about the causes and origins of genocides. It is true that most historians have been reluctant to consider the common features of different processes of annihilation, preferring to emphasize the uniqueness of each historical process. But the levels of analysis applied to each specific historical situation have been both numerous and diverse.

For example, a bewildering variety of approaches has been called upon to explain the Nazi genocide, including studies of the development of Nazi ideology, ${ }^{14}$ the role of racism and/or anti-Semitism, ${ }^{15}$ the role played by anti-Communist and counterrevolutionary struggle, ${ }^{16}$ the importance of the confiscation of Jewish property, ${ }^{17}$ the role of bureaucracy in organizing the extermination, ${ }^{18}$ the genealogy of Nazi violence, ${ }^{19}$ and the importance of Jewish identity as something complex, ambiguous, and at odds with the hegemonic idea of a Europe built on the nation-state. ${ }^{20} \mathrm{~A}$ similar mixed set of approaches has been applied to Rwanda, ${ }^{21}$ Cambodia, ${ }^{22}$ and other genocides.

On the other hand, there have been far fewer comparative studies, and those that have been conducted are largely from the past fifteen years or so. The reason for this is, as was previously mentioned, that many historians feel that a search for shared features and causal explanations would deny the historical uniqueness of different instances of genocide, particularly the Nazi annihilation of the Jewish population in Europe. Some of the comparative studies, however, deserve special mention (in particular those that examine the similarities and differences between the Armenian and the Jewish genocide) as certain key works have formed the basis of other comparative studies.

One of the best-known authors in comparative genocide studies, the US-Armenian genocide scholar Vahakn Dadrian, has argued in several works that it is both possible and desirable to compare the genocide of the Armenian and Jewish peoples. His work, in fact, has traced lines of convergence and divergence between the Jewish and the Armenian genocides. Among other factors, similarities include the minority status of both peoples and their history of persecution, their vulnerability in the territories where they lived, the presence of the necessary social conditions and structures for their annihilation, and the crucial roles played by political parties-the German National Socialist party and the Ittihad party of the Young Turks. More recently, Dadrian has included the 1994 Rwandan experience in his comparative analysis 
of genocide. ${ }^{23}$ In his 2004 article "Patterns of Twentieth Century Genocides: The Armenian, Jewish, and Rwandan Cases," Dadrian traces a thread through three genocidal processes in which the victims were chosen because of their ethnicity, even though ethnicity is a questionable concept in the case of Rwanda, where tensions between Hutu and Tutsi-groups that shared the same language, culture, and religion-were exacerbated by Belgian colonialism in the twentieth century. Be that as it may, such discussion does not diminish Dadrian's argument. ${ }^{24}$

Another example of comparative genocide studies can be found in Ben Kiernan's work. Like Dadrian, Kiernan began by specializing in a particular instance of genocide, the Khmer Rouge genocide, before moving on to comparative studies. His aim has been to situate the Cambodian massacres within a historical sequence of mass killings, including, of course, the most emblematic case of the twentieth century, the Holocaust. ${ }^{25}$ Unlike Dadrian, however, Kiernan had to come to terms with the fact that the Cambodian genocide was carried out essentially for political reasons, while the UNCG expressly excludes crimes against political groups. Accordingly, Kiernan compares the Holocaust and the Armenian genocide not with Rwanda but with three cases where the political-ideological nature of genocide is obvious: Cambodia, where state-sponsored killing was carried out in the name of radical Communism; Indonesia, which suffered a vast anti-Communist purge in the mid 1960s; and East Timor, where a dispute over self-determination with the colonial power, Portugal, was followed by 25 years of brutal Indonesian military occupation.

After analyzing the discourses surrounding these different genocides, Kiernan concludes that racism is always used to construct the "enemy." However, Kiernan argues that racism should be construed in a broad sense as focusing on ethnic, religious, or political affiliations. In fact, racist ideology gives meaning to the processes of stigmatization and subsequent annihilation, regardless of the actual concepts used to describe and identify the enemy in any specific case. Kiernan also claims that territorial expansion plays a fundamental role in genocidal states, as do various ways of idealizing a peasant population that is supposedly "less civilized" and, therefore, less exposed to the "evils of urban life," both material and moral.

Kiernan and Dadrian make different assumptions about causation, and these assumptions are implicit in their choice of examples. Thus, Dadrian tends to emphasize ethnic hatred, while Kiernan emphasizes ideological factors. This is true even when they are discussing the same genocides-the Armenian Massacres and the Nazi Holocaust. Although these are mostly differences in emphasis rather than substance, they have the potential to create different and potentially contradictory explanations of genocidal social practices.

A third example is the case of Enzo Traverso, an Italian historian who proposes an interesting and unorthodox historical sequence that takes the Holocaust as its endpoint rather than its starting point. In his 2003 book, The Origins of Nazi Violence, Traverso traces the legacy of European violence that created Nazism, especially genocides committed under European colonialism in the late nineteenth and early twentieth centuries. He thus examines the German annihilation of the Herero and Nama peoples of Namibia at the beginning of the twentieth century, and Mussolini's use of poison gas against tribesmen during the Italian conquest of Abyssinia in 1935, which Henry Huttenbach has seen as a precursor to the Nazi gas chambers. ${ }^{26}$

Working outside of the English-speaking world, Traverso rejects the notion of common totalitarian threads between Nazism and Stalinism. This is in sharp contrast to the approach of conservative historian Ernst Nolte, who sees Nazism as a 
European response to the Bolshevik terror from Asia. ${ }^{27}$ In Traverso's view, Nazi genocidal policy is linked to the legacy of colonialism through the concepts of total war and conquest. Traverso shows that the Nazi atrocities that so shocked European public opinion after the Second World War had been committed without causing much moral concern. This approach has much in common with those of Dirk Moses, Donald Bloxham, Juergen Zimmerer, Dominik Schaller, and a group of Anglo-Saxon and Australian scholars devoted to exploring the link between genocide and imperialism. ${ }^{28}$

In France, Jacques Semelin has also mapped out a comparative study of Nazi Germany, Rwanda, and former Yugoslavia. He highlights the discourses used to stigmatize otherness, the international context, the role of the media, and the dynamics of mass murder, among other factors. Finally, in analyzing the political uses of massacres in these three case histories, Semelin distinguishes between "destroying to subjugate" and "destroying to eradicate," adding a third possible category: "destruction to revolt." 29

This review of comparative studies is necessarily incomplete, and I have omitted some studies because of their questionable ideological legitimacy. ${ }^{30} \mathrm{I}$ would like to add some comments on my own comparative work, in which I set out to account for the similarities and differences between the Nazi genocide and state terrorism in Argentina. While recognizing the obvious differences between the two in terms of size, scale, and method of implementation, my work emphasizes some striking structural similarities, including the central role played by concentration camps in destroying subjectivity. I have also created the concept of genocidal social practices to account for shared features of the concentration camp system in different historical contexts. I define genocidal social practices in these cases as "a technology of power that is intended to destroy social relations based on autonomy and cooperation by killing a significant portion of society (significant in numbers or influence) and that then attempts to create new social relations and identity models through terror."31

One of my main concerns has been to show the different ways in which annihilation has served to transform social relations. Genocide is not the only way to transform societies, but, together with revolution, it has been a very successful method during the twentieth century. However, although revolutions have also destroyed and reorganized social relations, they have not necessarily done so through mass annihilation. This is the main difference between revolution and genocide. In such a perspective, what many modern cases of genocide have in common (and Nazism and Argentina share) is that the perpetrators sought to annihilate their enemies both materially and symbolically. Not just their bodies but also the memory of their existence was supposed to disappear, forcing survivors to deny their own identity. In this sense, the disappearances outlast the destruction of war, and the effects of genocide do not end but rather only begin with the deaths of the victims. In short, this kind of objective view of genocidal destruction is the transformation of the victims into nothing and the survivors into nobodies.

To sum up, our understanding of the causes and consequences of genocidal processes is far from complete. But we can also look on this as a strength, not a weakness, given that all historical events have multiple causes, including the different motives of the various actors involved, and multiple consequences. The rich profusion of recent publications has brought new perspectives to bear on the logic of mass annihilation of populations and the political, social, symbolic, and conceptual consequences generated by destruction and terror in the societies in which genocide has taken place. 


\section{Perspectives on Prevention}

An important feature of genocide studies over the last twenty years has been an increased emphasis on applying academic theories to preventing genocide. However, the predominant thinking in the Anglo-Saxon world has tended to oversimplify the relationship between theory and prevention, which is tricky and dangerous.

Since the late $1990 \mathrm{~s}$, there have been various attempts to establish early warning mechanisms capable of recognizing potentially genocidal situations from a number of variables. One of the most sophisticated is that of Barbara Harff and Ted Gurr, which uses six key variables (among many others) to predict genocide: (1) degree of political conflict, (2) existence of previous genocide, (3) ideology of the ruling elite, (4) regime type, (5) ethnic situation, and (6) openness to trade. It also identifies a number of genocide "accelerators." 32

Beyond the problems of statistical inference and the potential discussions surrounding each of the variables, the core questions are:

1. Is it indeed possible to identify common features of genocides, and, more importantly,

2. What is the next step in identifying potentially genocidal situations?

In the twenty-first century there have been a number of publications on prevention by US-based scholars and officials putting forward the hegemonic view. This type of work lacks the seriousness of Harff and Gurr's and focuses only on the political will of the different actors-notably the US-to intervene in potentially genocidal situations.

Two well-known examples of this widespread and banal approach are the reports Preventing Genocide, which appeared under the Bush administration in 2008, and MARO: Mass Atrocity Response Operations, which was published under the auspices of the Obama administration in $2010 .{ }^{33}$

These kinds of perspectives reflect a point of view that is clearly discernible in Samantha Power's A Problem from Hell: America and the Age of Genocide, which focuses on genocide in Cambodia, Rwanda, and the Balkans. Power, a freelance war correspondent during the crisis in the former Yugoslavia, has done perhaps more than anyone else to shape the way in which US citizens view their country's relationship to genocide. ${ }^{34}$ Power's book can be seen as a denouncement of "failure" on the part of the United States to prevent, slow down, or hinder the development of genocidal processes when it has had the power to do so.

The authors of these perspectives have not fully thought through the implications of their ideas. For example, a key idea running through such works is the need to limit national sovereignty in order to prevent genocidal practices. But, simultaneously, no one points out that the US has refused to sign different international treaties on the grounds that to do so would limit state sovereignty. Indeed, the US has been so determined not to sacrifice an inch of its sovereignty that it voted against the ICC Statute at the Rome Conference in 1998, which was established precisely to prosecute individuals for genocide, crimes against humanity, and war crimes.

Moreover, these perspectives do not make it clear to whom the alleged perpetrators of such crimes are supposed to surrender state sovereignty. There is no suggestion in these perspectives that greater powers should be vested, for example, in the United Nations, in regional organizations, or in international courts. So, in the absence of any clearly defined international body with powers to determine that 
genocide or other heinous crimes are being committed and to intervene accordingly, charges of genocide could easily be manipulated. From here it would be a short step to justify unilateral diplomatic, economic, or military intervention anywhere in the world. Conversely, no international, regional, or US organization would have the power to intervene if US citizens committed similar crimes at home or abroad. Immunity would very quickly become impunity.

An early critique of interventionist policies can be found in Thomas Cushman's article "Is Genocide Preventable?" 35 Cushman argues convincingly that these approaches to preventing genocide rest on two unproven assumptions: (1) that advance warning of genocide would lead to effective measures to prevent it and (2) that modernity and genocide are opposing forces. The second of these assumptions, of course, implies that with sufficient political will genocide could be eradicated by "modern" methods.

Cushman calls this a "naturalistic approach [that] favors structural forces over human agency in the explanation of genocide." Referring to "expressions of ideological commitment to the idea of prevention to genocide," he notes that "[t]here is ... a rather glaring discrepancy between such ritual statements and the magnitude and complexity of the phenomenon of genocide itself." 36

Cushman's solution is much less developed than his critique. However, his intuition that modernity and genocide are not necessarily at loggerheads suggests that useful contributions to prevention could come from researching those modern features that actually facilitate the processes of genocide, thus developing a kind of work similar to the Frankfurt School scholars such as Theodor Adorno, Walter Benjamin, or Max Horkheimer or the work of Zygmunt Bauman, among others. This is likely to lead to much farther-reaching changes than political will could.

Once we understand genocide as process, a series of actions occurring over time, we cannot fail to notice that many of its early stages (stigmatization, harassment, isolation) exist in virtually all modern states and not just in sub-Saharan Africa or the Middle East, as ethnocentric "interveners" believe. Current examples range from the persecution of Roma in France, Italy, and Spain and limitations on the civil rights of Muslims in Germany and France to the anti-immigration laws of Arizona and a battery of discriminatory measures against Latinos in the US generally.

The issue of prevention has tended to divide genocide scholars into those who hold more ethnocentric and discriminatory views on the causes of genocide and who call for economic sanctions and US military intervention in order to "civilize the savages" of third-world Africa, Asia, and Latin America, on the one hand, and those who resist these positions by retreating to their ivory towers in an attempt to separate their academic work from its political consequences, on the other hand. There are, of course, other scholars who criticize and reject this use of ethnocentric humanitarianism to legitimize new ways of imperialism.

Perhaps human rights activists from different cultural backgrounds will be able to use academic research to draw different political conclusions. I am referring to members of organizations further away from the hegemonic powers' places of decision making, organizations such as the World Social Forum, the Permanent Peoples' Tribunal, and African and Latin American regional organizations, all of which include a large number of academics. They are perhaps more likely to take into account the complexity of genocide and the necessarily complex nature of any political strategy of prevention. 


\section{A Cultural Issue}

Numerous studies have shown that language affects thought processes. There are huge differences, for example, between philosophical works written in English and works written in other European languages, and these differences are even greater when works are written in Hebrew, Chinese, or Arabic. Each language imposes certain conditions, restraints, and directions on both the form and content of thought, giving rise to different-and rewarding-academic approaches.

Unfortunately, although many academic fields have been victims to the steamroller of globalization, this is particularly true of genocide studies, which is a relatively recent discipline and has developed almost entirely in the English-speaking world. Also, genocide studies have been more permeated than most by the hegemony of English in the twenty-first century. As a result, cultural exchanges, where they exist at all, are nearly always one-sided. For example, work produced in Slavic or Romance languages-two key areas of development in the twenty-first centurydiscusses, cites, and questions the literature written in English or German, but not so the other way around.

There are many reasons for chronic Anglo-centrism in our field. One problem is the absurd editorial policies of the Anglo-Saxon world, which have eliminated funding for translations since the 2008 economic crisis, arguing that the lingua franca of academia is English and that work should be submitted in English only for evaluation prior to publication. This effectively limits those authors who have learned to write in English because of family, educational opportunities, or other contact with the English-speaking world.

Another problem is that even where funding is available, specialized journals, the backbone of academic research, have no policies prioritizing the translation of work produced in different cultures. Again, this contrasts with developments in Latin America and East Asia, where there are policies for the more or less systematic translation of classic and contemporary works from English, German, or French.

And now for a cautionary tale. There has been a wealth of articles published in Spanish and Bosnian, among other languages, in recent years. ${ }^{37}$ Their treatment of genocide is broader than that found in English and yet they will remain forever inaccessible to monolingual scholars unless publishers and journals provide updates on developments and discussions that occur outside their own cultural context. This one-sidedness will continue to compartmentalize genocide studies, with the more ethnocentric scholars believing that genocide happens precisely where "no one speaks English" (whether this be North Africa, sub-Saharan Africa, Southeast Asia, Southeast Europe, the former Soviet Union, or Latin America).

As a result, most researchers-Anglo-Saxon or otherwise-are forced to examine different cases of genocide through the distorted lens of work produced by the AngloSaxon world. The authors of this work frequently have a poor command of languagesSlavic languages, Arabic, Chinese, Spanish, Swahili, or African dialects-and must enlist the help of local translators and interpreters in an attempt to overcome cultural barriers, such as ignorance of the history and traditions of the place, the logic of language and genealogy, the way that conflicts are structured, and so forth.

Often, as happened in nineteenth-century anthropology, they end up trying to make an incomprehensible reality fit Anglo-Saxon models of understanding, thus distorting or changing the data. With regard to Latin America, a clear and amusing example is Oliver Stone's film South of the Border, which contrasts the US media view of Latin America with the voices of twenty-first-century democratic presidents 
from the region (characterized in the US political mainstream as "populists," "demagogues," "paranoics," etc.). ${ }^{38}$ Latin America is the closest region in geographical and cultural terms to the US parent culture. What will researchers from the selfstyled parent culture make of the worldviews of Slavic, Oriental, or African cultures? If Semitic, Slavic, and Oriental cultures are often misunderstood and even demonized, African cultures are still considered by some as a missing link in human evolution-a primitive state that would be better left behind.

\section{Conclusions}

In the cycle of life, young people become adults when they leave their parents' house and set up their own homes elsewhere. This involves exposure to the outside world which is often a frightening but also refreshing and infinitely rewarding experience. Using life cycle as a metaphor, it can be argued that the field of genocide studies emerged from an attempt to work through a trauma in the heart of Europe. Nevertheless, it was adopted by Anglo-Saxon parents and grew up in a cozy American home frequented by German relatives and visited occasionally by French neighbors.

After nearly half a century of existence, it may be time to get out of the parents' house and live a truly independent life. This does not mean denying the parents' legacy. On the contrary, unlike adolescents, adults are able to question what needs to be questioned and salvage the legitimate and important parts of tradition. To my mind, this is the greatest challenge for genocide studies in each of the three main problem areas outlined in this article.

\section{Notes}

1. Translated from Spanish by Douglas Andrew Town.

2. See, for example, Frank Chalk and Kurt Jonassohn, The History and Sociology of Genocide: Analysis and Case Studies (New Haven: Yale University Press, 1990); Israel Charny, How Can We Commit the Unthinkable? Genocide: the Human Cancer (Boulder, CO: Westview, 1982); Helen Fein, Accounting for Genocide: National Responses and Jewish Victimization During the Holocaust (New York: Free Press, 1979); Helen Fein, ed., Genocide Watch (New Haven: Yale University Press, 1992).

3. Leo Kuper, Genocide: Its Political Use in the Twentieth Century (New Haven: Yale University Press, 1981), 39.

4. Henry Huttenbach, "From the Editor: Towards a Conceptual Definition of Genocide," Journal of Genocide Research 4, no. 2 (2002): 167-75.

5. According to the UNCG, genocide means any of the following acts committed with intent to destroy, in whole or in part, a national, ethnical, racial or religious group, as such:
(a) Killing members of the group;
(b) Causing serious bodily or mental harm to members of the group;
(c) Deliberately inflicting on the group conditions of life calculated to bring about its physical destruction in whole or in part;
(d) Imposing measures intended to prevent births within the group;
(e) Forcibly transferring children of the group to another group.

See Convention on the Prevention and Punishment of the Crime of Genocide, 9 December 1948, 78 U.N.T.S. 277, Article II, http://www.preventgenocide.org/law/convention/text.htm (accessed 21 October 2011).

6. Matthias Bjornlund, Eric Markusen, and Martin Mennecke, "What is Genocide? A Search for Common Grounds between Legal and Non-Legal Definitions" (paper presented at the First International Meeting on Genocidal Social Practices, Buenos Aires, 10-15 November 2003), 2.

7. Ibid., 28 . 
8. William Schabas, "The Law and Genocide," in The Oxford Handbook on Genocide Studies, ed. Donald Bloxham and A. Dirk Moses (Oxford: Oxford University Press, 2010), 141.

9. William Schabas, Genocide in International Law, 2nd ed. (Cambridge: Cambridge University Press, 2009).

10. Convention on the Prevention and Punishment of the Crime of Genocide, Article II.

11. Barbara Harff and T.R. Gurr, "Toward Empirical Theory of Genocides and Politicides: Identification and Measurement of Cases since 1945," International Studies Quarterly 32 , no. 3 (1988): 359-71.

12. Such discussions are present in the trials in national and international courts concerning the current cases of Bosnia-Herzegovina, Argentina, Colombia, Cambodia, and Uruguay.

13. Political groups (and wider terms such as "any group" or "any community" as well as sexual groups, health groups, and others) have been included in definitions of genocide contained in the penal codes of a number of states, including Bangladesh, Colombia, Ivory Coast, Costa Rica, Ethiopia, France, Finland, Lithuania, Panama, Peru, Portugal, Romania, and Uruguay. This trend has increased in recent years. Argentina has not yet included genocide in its penal code, but all of the bills presented in its history-including one under discussion in parliament in 2011-protect political and other groups.

14. See, for example, Lucy Dawidowicz, The War Against the Jews (New York: Pocket Batham, 1986); Daniel Goldhagen, Hitler's Willing Executioners (New York: Vintage, 1997); Omer Bartov, Mirrors of Destruction: War, Genocide and Modern Identity (Oxford: Oxford University Press, 2000).

15. See, among others, Yehuda Bauer, Rethinking the Holocaust (New Haven: Yale University Press, 2002); David Bankier, Probing the Depths of German Antisemitism: German Society and the Persecution of the Jews, 1933-1941 (New York: Berghahn, 2000). Works by Hebrew scholars are particularly notable.

16. For a key work on this topic, see Arno Mayer, Why Did the Heavens not Darken? The "Final Solution" in History (New York: Pantheon, 1989).

17. Götz Aly, Hitler's Beneficiaries: Plunder, Racial War and the Nazi Welfare State (New York: Holt, 2008).

18. See Raúl Hilberg, The Destruction of the European Jews (Chicago: Quadrangle, 1961); Hannah Arendt, Eichmann in Jerusalem: A Report on the Banality of Evil (New York: Penguin, 1994); Zygmunt Bauman, Modernity and the Holocaust (Ithaca: Cornell University Press, 2000).

19. Enzo Traverso, La violence nazie: Une généalogie européenne [Nazi violence: A European genealogy] (Paris: La Fabrique, 2002).

20. See, for example, Zygmunt Bauman, Modernity and the Holocaust; Jean Claude Milner, Les penchants criminels de l'Europe démocratique [The criminal tendencies of democratic Europe] (Paris: Editions Verdier, 2003); Jean Claude Milner, Le Juif de savoir [The Jew of knowledge] (Paris: Editions Grasset et Fasquelle, 2006).

21. In the case of Rwanda there are several perspectives: Alison des Forges, Leave None to Tell the Story: Genocide in Rwanda (New York: Human Rights Watch, 1999); Robert Melson, "Modern Genocide in Rwanda: Ideology, Revolution, War and Mass Murder in an African State," in The Specter of Genocide: Mass Murder in Historical Perspective, ed. Robert Gelatelly and Ben Kiernan (New York: Cambridge University Press, 2003), 32538; Rene Lemarchand, "The 1994 Rwanda Genocide," in Century of Genocide: Critical Essays and Eyewitness Accounts, ed. Samuel Totten and William S. Parsons (New York: Routledge, 2009), 404-22; Scott Straus, The Order of Genocide: Race, Power and War in Rwanda (Ithaca: Cornell University Press, 2006); Gabriel Péries and David Servenay, Une guerre noire: Enquete sur les origins du génocide rwandais (1959-1994) [A black war: An investigation into the origins of the Rwandan Genocide (1959-1994)] (Paris: La Découverte, 2007).

22. For perspectives on Cambodia, see Ben Kiernan, The Pol Pot Regime: Race, Power, and Genocide in Cambodia under the Khmer Rouge, 1975-79 (New York: Yale University Press, 1996); Alexander Laban Hinton, Why Did They Kill? Cambodia in the Shadow of 
Genocide (Berkeley: University of California Press, 2005); Craig Etcheson, After the Killing Fields: Lessons from the Cambodian Genocide (Texas: Texas Tech University Press, 2005).

23. See Vahakn N. Dadrian, "The Common Features of the Armenian and Jewish Cases of Genocide: A Comparative Victimological Approach" in Victimology: A New Focus, Violence and Its Victims, ed. Israel Drabkin and Emilio Viano (Lexington, MA: D.C. Heath, 1975), 99-120; Helen Fein, Accounting for Genocide); Vahakn N. Dadrian, "The Comparative Aspects of the Armenian and Jewish Cases of Genocide: A Sociohistorical Perspective" in Is the Holocaust Unique?, ed. Alan S. Rosenbaum, 3rd ed. (Boulder, CO: Westview Press, 2009), 139-174; Vahakn N. Dadrian, "The Historical and Legal Interconnections between the Armenian Genocide and the Jewish Holocaust: From Impunity to Retributive Justice," Yale Journal of International Law 23, no. 2 (1998): 504-59. For an account of the Rwandan genocide, see Vahakn N. Dadrian, "Patterns of Twentieth Century Genocides: The Armenian, Jewish, and Rwandan Cases," Journal of Genocide Research 6, no. 4 (2004): 487-522.

24. This point was made by the International Criminal Tribunal that tried the crimes in Rwanda, and Dadrian has conceded it as well. It has also been well received by Eric Markusen and Alison Des Forges, among others. See Prosecutor v. Georges Anderson Nderubumwe Rutaganda, Judgement (6 December 1999), International Criminal Tribunal for Rwanda; Bjornlund, Markusen, and Mennecke, "What is Genocide?"; des Forges, Leave None to Tell the Story.

25. For Kiernan's most complete work on Cambodia, see Ben Kiernan, The Pol Pot Regime. For a comparative analysis, see Ben Kiernan, "Twentieth-Century Genocide: Underlying Ideological Themes from Armenia to East Timor," in Gelatelly and Kiernan, The Specter of Genocide, 29-50.

26. See Enzo Traverso, The Origins of Nazi Violence, trans. Janet Lloyd (New York: New Press, 2003). For Huttenbach's work, see Henry Huttenbach, "The Fatal Links in the Genocide Chain: From Armenia (1915) to the Final Solution (1942)" (paper presented at First International Meeting on Genocidal Social Practices, Buenos Aires, 10-15 November 2003).

27. See Enzo Traverso, Le Totalitarisme: Le XXe siècle en débat [Totalitarianism: The twentieth century debate] (Paris: Seuil, 2001).

28. A. Dirk Moses and Dan Stone, eds., Colonialism and Genocide (New York: Routledge, 2007); A. Dirk Moses, ed., Empire, Colony, Genocide: Conquest, Occupation and Subaltern Resistance in World History (New York: Berghahn, 2009); Donald Bloxham, The Great Game of Genocide, Imperialism, Nationalism, and the Destruction of Ottoman Armenians (Oxford: Oxford University Press, 2007).

29. Jacques Semelin, Purifier et détruire: Usage politiques des massacres et génocides [Purify and destroy: Political uses of massacres and genocides] (París: CERI, 2007).

30. Among those I have omitted because of their questionable theories and politics are Ernst Nolte and Andreas Hillgruber. See Ernst Nolte, Der Europäische Bürgerkrieg, 19171945: Nationalsozialismus und Bolschewismus [The European Civil War, 1917-1945: Nazism and Bolshevism] (Munich: Herbig, 2000); Andreas Hillgruber, Zweierlei Untergang: Die Zerschlagung des Deutschen Reiches und das Ende des europäischen Judentums [Two kinds of ruin: The fall of the German Reich and the end of European Jewry] (Berlin: BRD, 1986). Nolte portrays Nazism as a "European reaction" to "Bolshevik terror," comparing the repressive methods of Nazism and Stalinism in order to establish causal connections between the two and minimize the role played by Germany's-and Europe'sruling classes in implementing genocide. Thus, the Nazi genocide, in Nolte's view, was simply a "defensive" response by civilized Europe, shocked at the "barbarism" of the "Slavic" Russian revolution. In other words, it was Communism that unleashed total war in Europe. Hillgruber shocked German and European scholars with his analysis of the "end" of European Jewry and the "tragedy" of the German army on the Eastern Front at the end of World War II. Hayden White has insightfully pointed out that 
Hillgruber pushes discourse to its limit by describing the sufferings of the German army as a "tragedy" while referring to the sufferings of European Jews with the neutral and impersonal term "end." Answering calls for a ban on Hillgruber's work, White argues that Hillgruber's was just one more way of "emplotting" a historical discourse. The real question was how to account for the ideological implications of different discourses. For White's approach to the Holocaust, see Hayden White, "Historical Emplotment and the Problem of Truth," in Probing the Limits of Representation: Nazism and the "Final Solution," ed. Saul Friedlander (Cambridge, MA: Harvard University Press, 1992). A more acceptable but clearly conservative approach is found in the work of Eric Weitz, who attempts to link Nazism, Stalinism, and genocide in Cambodia. Weitz suggests revolutionary upheaval as the main explanation for the appearance of genocidal social practices in these three political and social experiments. As can be seen very clearly from these examples, the ideological implications of any given approach may be more or less obvious, more or less explicit, but they cannot be eliminated and are always implicit in the historical examples chosen for comparison. See Eric D. Weitz, "The Modernity of Genocides: War, Race and Revolution in the Twentieth Century," in Kiernan and Gelatelly, The Specter of Genocide, 53-73.

31. Daniel Feierstein, El genocidio como práctica social: Entre el nazismo y la experiencia argentina [Genocide as social practice: Between Nazism and the Argentinian experience] (Buenos Aires: FCE, 2007).

32. Barbara Harff and Ted Gurr, "Toward Empirical Theory of Genocides and Politicides"; Barbara Harff and Ted Gurr, "Systematic Early Warning of Humanitarian Emergencies," Journal of Peace Research 35, no. 5 (1998): 551-79; Barbara Harff, "No Lessons Learned from the Holocaust?," American Political Science Review 97, no. 1 (2003): 57-73.

33. Madeleine K. Albright, William S. Cohen, United States Holocaust Memorial Museum, The American Academy of Diplomacy and the Endowment of the US Institute of Peace, Preventing Genocide: A Blueprint for U.S. Policymakers (Washington, DC: Genocide Prevention Task Force, 2008); Sarah Sewall, Dwight Raymond, and Sally Chin, MARO: Mass Atrocity Responses Operations; A Military Planning Handbook (Cambridge, MA: Harvard Kennedy School / Carr Centre for Human Rights Policy, 2010). Genocide Studies and Prevention: an International Journal has devoted two special issues to these reports with critical analyses by leading scholars in the field. See Genocide Studies and Prevention 4, no. 2 (2009), which deals with Preventing Genocide, and Genocide Studies and Prevention 6, no. 1 (2011), which deals with the MARO Report.

34. Samantha Power, "A Problem from Hell": America and the Age of Genocide (New York: Harper Collins, 2007).

35. Thomas Cushman, "Is Genocide Preventable? Some Theoretical Considerations," Journal of Genocide Research 5, no. 4 (2003): 523-42.

36. Ibid., 533, 530 .

37. There are several examples of such works: the different works published by the teams under the direction of Smail Cekic in the University of Sarajevo; different scholars working in Colombia like Alejandro Castillejo Cuéllar or Andrei Gomez Suarez; the works by Gabriel Gatti, Manuel Reyes Mate, Alberto Sucasas, and other authors in Spain; Alvaro Rico Fernández, Oscar López Goldaracena, and Carlos Demasi in Uruguay; Luis Alegría, Cristian Gutiérrez, and Elías Padilla Ballesteros in Chile; my own teams of scholars in different universities in Argentina (Buenos Aires, Tres de Febrero), which include Guillermo Levy, Lior Zylberman, Emmanuel Taub, Tomas Borovinsky, Eva Camelli, Perla Sneh, Adriana Taboada, among many others.

38. Oliver Stone, South of the Border, 2009. 